\title{
INNOVATIONS AS THE MAIN CHALLENGE IN THE FIELD OF HEALTH TOURISM IN LATVIA
}

\author{
Jelena Lukjanova1, Tatyana Odinokova ${ }^{2}$ \\ ${ }^{1,2}$ Information Systems Management Institute (ISMA), Riga (Latvia) \\ e-mails: ${ }^{1}$ Jelena.lukjanova@isma.lv, ${ }^{2}$ tatjana.odinokova@isma.lv
}

Received: 01 March 2020; Accepted: 13 April 2020; Published: 01 May 2020

\begin{abstract}
:
Globalization is the process which takes places in the modern world, fierce competition in the tourism market, growing demand for tourists, changing tourist preferences, development of information technologies - need point for the tourism industry, including health tourism sector, move to an innovative development path. Recognition at the state level of health sphere tourism as one of the priority areas of the national economy in Latvia opens up great opportunities for the development of innovative activities in this area. This article discusses the main directions of state policy in the field of tourism, factors affecting the innovative development of the health tourism sector in Latvia, including the role in health tourism cluster.
\end{abstract}

Key words: innovation, tourism, health tourism, SPA \& Wellness tourism, cluster, resort.

JEL classification: $\mathrm{O} 30 ; \mathrm{O} 38 ; \mathrm{O} 40$

How to Cite:

Lukjanova, L., Odinokova, T. 2020. Innovations as the main challenge in the field of health tourism in Latvia. Access journal, ACCESS Press, 1(1): 39-52. DOI: https://doi.org/10.46656/access.2020.1.1(3)

\section{INTRODUCTION}

One of the main problems in Latvian tourism industry is lack of competitiveness tourism products offered, poor popularity in the world as a resort and recreation place, and underdeveloped tourism infrastructure outside Riga. All this inevitably leads needs for the industry to transition to the path of innovative development, including product, technological, marketing, organizational innovations. Such transition is possible only if state, entrepreneurs and the scientific sector are involved in the process of innovative development.

\section{MATERIALS AND METHODS}

Scientific knowledge is based on the constant search for appropriate methodological approaches and research methods. For thorough study problems of the innovative development of health tourism in Latvia, methodological issues of paramount importance.

Authors applied for systematic approach, including analysis and synthesis of the management object, in this case, sphere of health tourism, as well as a managerial decision made at state level. The importance of 
systematic approach of tourism research is currently growing due to fact that processes of globalization and integration of political, economic, cultural and information space have caused changes in the tourist space. Globalization has affected the tourism world, which is becoming more and more united, countries that makes it up are increasingly interconnected and interdependent. In order to get an idea of the state of tourism in a particular country and evaluate this state, it is imperative to take into account the state of tourism in other countries and whole world.

Authors applied for method of "statistical observation" in the form of systematic collection of information on dynamics of tourism on a global scale and the scale of Latvia, the dynamics of the proportion of innovative enterprises in Latvia. The sources of information in this study were:

- reports, monitoring results of tourism industry, as well as innovative activity of enterprises, in particular, UNWTO World Tourism Barometry, OECD Economic Surveys: Latvia, Global Innovation Index 2018 rankings, European Innovation Scoreboard (EIS), etc.

- reporting by Central Statistical Office of Latvia on tourism sector of the economy and innovative activity of Latvian enterprises.

Authors analyzed documents that regulate direction and development of innovation policy of Latvia, as well as the main regulatory acts regulating tourism sector of Latvia, including health.

\section{RESULTS AND DISCUSSION}

Nowadays, tourism (Travel \& Tourism) is one of the largest and dynamically developing sectors of the global economy, it creates jobs, promotes export.

In $2019,1.5$ billion international tourist arrivals were registered in the world, which is $4 \%$ more compared to the previous year. Tourist flows around the world show steady growth for the tenth consecutive year. However, it is necessary to note a slowdown in growth compared to 2017 (+ 7\%) and $2018(+6 \%)$. Tourism growth in 2019 was negatively impacted by uncertainties around Brexit, the collapse of Thomas Cook and several low-cost airlines in Europe., Geopolitical and social tensions and a slowdown in the global economy.

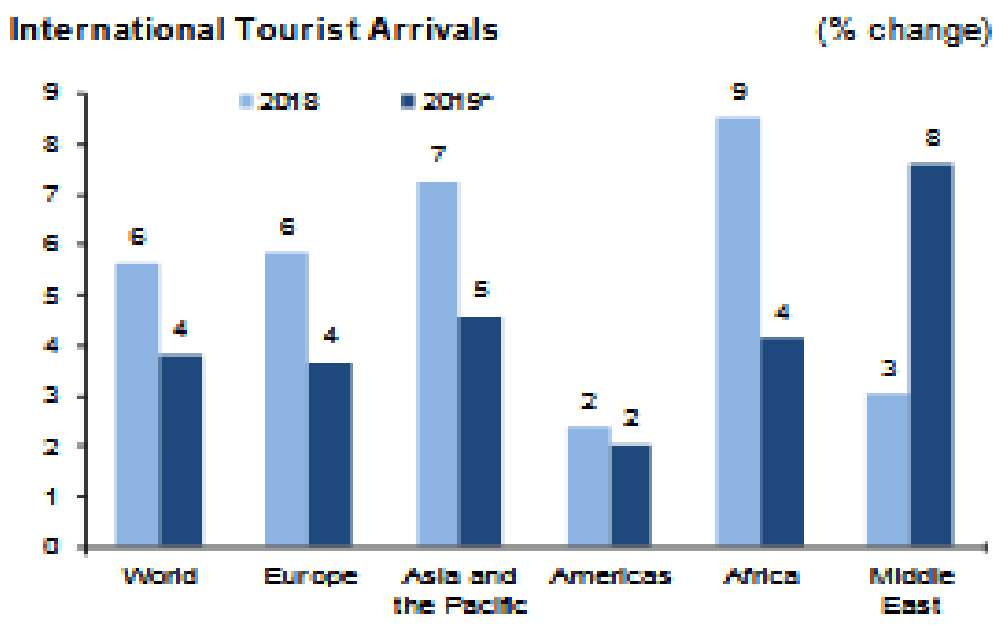

Figure 1. International tourist arrivals dynamic, \% (UNWTO (2020) 
* Provisional data

The fastest growing region for international tourist arrivals in 2019 was Middle East $++8 \%$, which is almost twice as much compared to last year). In turn, growth in Asia-Pacific region slowed down, although it remained above average and the number of international arrivals increased by 5\%. In Europe, growth was slower than in previous years $(+4 \%)$, while it continues to lead in the number of international arrivals, having received 743 million international tourists in 2019 (51\% of the world market). America (+ 2\%) showed an ambiguous picture as many island destinations in the Caribbean strengthened their recovery from the 2017 hurricanes, while arrivals in South America declined in part due to ongoing social and political turmoil. Limited data for Africa (+4\%) indicate continued high results in North Africa $(+9 \%)$, while in subSaharan Africa, growth rates slowed in $2019(+1.5 \%)$. UNWTO predicts an increase in the number of foreign tourists in the world in 2020 by $3-4 \%$.

Same time, as organization notes, approximately same growth in tourist flow as in 2019 is forecasted for 2020 (from 3\% to 4\%), which suggests that tourism has become one of the fastest growing and most stable sectors of the world economy. Major sporting events, including the Tokyo Olympics, and cultural events such as EXPO 2020 in Dubai are expected to have a positive impact on the sector.

In 2019, 2.85 million foreign and local guests were served in tourist residences (hotels and guest houses) in Latvia, which is $1.6 \%$ more than in 2018. Compared to 2018, the number of nights spent by guests increased by $2.6 \%$ and reached 5.51 million. The average length of tourists stay in accommodation was 1.9 nights.

In $2019,1.95$ million foreign guests were served, which is $1.1 \%$ more compared to the previous year. In turn, the number of nights spent by foreign guests increased by $2.9 \%$, reaching 3.85 million nights. Most of the guests were received from Russia (279.4 thousand), Germany (243.0 thousand), Lithuania (209.5 thousand), Estonia (171.1 thousand), Finland (110.8 thousand) and the United Kingdom (108.0 thousand)

Table 1. Number of guests served in Latvian hotels and other tourist accommodation

\begin{tabular}{|l|c|c|c|}
\hline & $\mathbf{2 0 1 7}$ & $\mathbf{2 0 1 8}$ & $\mathbf{2 0 1 9}$ \\
\hline Total & 2577338 & 2808808 & 2853333 \\
\hline Foreign Tourists & 1778973 & 1925397 & 1945919 \\
\hline Local Latvian Tourists & 798365 & 883411 & 907414 \\
\hline
\end{tabular}

Source: Own calculations (info: Centrālā statistikas pārvalde, 2020)

Statistics shows slowdown in tourist flow. It has been noted that foreign tourists rarely choose Latvia as their travel destination, mainly they visit the three Baltic states (Lithuania, Latvia and Estonia). This circumstance is reflected, in particular, in the small number of nights spent by foreign tourists in Latvia. In these conditions, it is necessary to strengthen the marketing of Latvian tourism, clearly define the target audience, which will allow hotels and tour operators to understand in which direction to move. 
In 2016, direct contribution of the tourism industry in Latvia to the country's GDP amounted to about 1 billion euros, or $4.1 \%$. Direct tourism exports amounted to 783 million euros, representing $4.5 \%$ of total exports. Tourism itself provides 36 thousand jobs, together with related industries the tourism industry in Latvia provides almost 79 thousand jobs, or 8.9\% of total employment (OECD, 2018).

Tourism is characterized by high "multiplier" effect. According to World Tourism Organization, tourism has an indirect effect on development of more than 32 industries. So, the tourism industry uses the services of airports, banks, insurance organizations, etc., investing its share of money in their development. Accordingly, more of these funds will be spent domestically and will go to development, higher effect of the "multiplier" and vice versa. By influencing such sectors of economy as production of consumer goods, transport and communications, construction, medicine, agriculture, tourism, it accelerates the socioeconomic development of state.

Currently, global tourism industry is undergoing significant changes: tourist preferences are changing, there is a constant increase e-commerce, increasing the diversity and number of tourism products, there are new tourism goals. In this regard, conditions of further globalization and increased competition, Latvia needs to use competitive advantages in order to develop tourism products and territories with a high potential for long-term development. The goal of Latvian state tourism policy is sustainable development of tourism by increasing the competitiveness of tourism products in foreign markets. "The main guidelines for the development of Latvian tourism for period 2014-2020" as one of the main areas of activity include promoting the development of competitive tourism products by supporting development of new, innovative, high-value tourism products, tourism infrastructure development a) promoting the formation of regional tourism clusters and the inclusion of the Latvian tourism product in the general tourism offer of the countries of the Baltic Sea region (Ekonomikas ministrija, 2014).

The following definition of innovation has been adopted in Latvia: "Innovation is a process during which new ideas, developments and technologies in scientific, technical, social, cultural or other fields are embodied in marketable and competitive products and services."

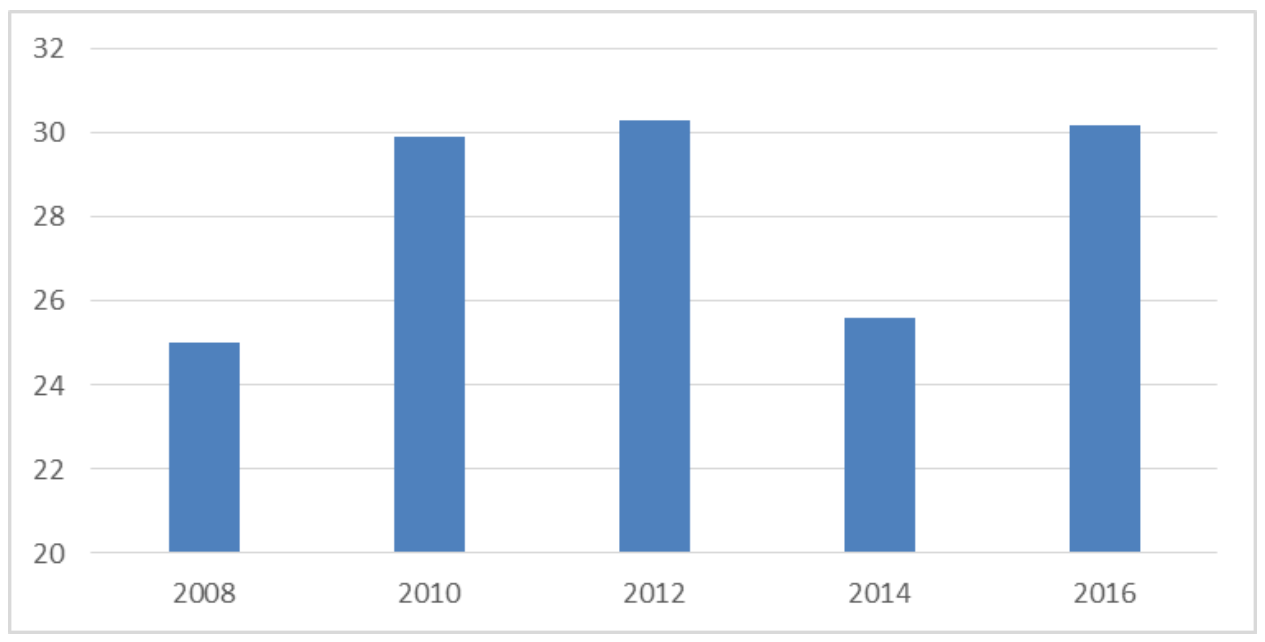

Figure 2. Dynamics of innovative share enterprises in Latvia, $\%$ of total number of enterprises 
Source: Latvijas statistikas gadagrāmata, 2018

In 2014-2016, innovatively active enterprises in Latvia accounted for $30.3 \%$ of total number of enterprises, innovatively active enterprises in service sector accounted for $28.5 \%$ of the total number of enterprises in this field.

According to Global Innovation Index 2018 rating, Latvia is 34th in the Global Innovation Index, Estonia is 24th, Lithuania is 40th. In Latvia, overall growth of innovative activity of enterprises is mainly associated with technological innovation, while innovation activity in the field of marketing and organizational innovation is much lower.

The main documents regulating the direction and development of innovation policy in Latvia are: The main directions of national industrial policy for 2014-2020 (Nacionālās industriālās politikas pamatnostādnes 2014. - 2020. Gadam), the Strategy for smart specialization (Viedās specializācijas stratēgija), Latvian national development for 2014-2020 (Latvijas Nacionālais attīstības plāns 2014. - 2020.gadam), Long-term development strategy of Latvia until 2030 (Latvijas ilgtspējīgas attīstības stratēgija līdz 2030. gadam), Main directions for the development of science, technology and innovation for 2014-2020(Zinātnes, tehnologijas attīstības un inovācijas pamatnostādnes 2014.-2020. Gadam). The basic document is European Union Development Strategy until 2020 - Europe 2020, developed in 2010 by the European Commission - Europe 2020. One of the three basic development priorities in the Strategy indicates reasonable growth - the transition to an economy based on knowledge and innovations (Europe 2020, 2010).

In relation of tourism, term "innovation" in Latvia is interpreted as follows: "Compared to existing offer on the market, new service is offered, new kind of existing service, an efficient technological process, production method, new or improved way of providing a product, etc., which helps company maintain and strengthen its position in the market, ensures competitiveness, prolongs the tourist season, increases turnover and creates other advantages" (Ekonomikas ministrija, 2014).

Despite the differences in the interpretation of the types of innovations, it can be recognized that tourism enterprises that embarked on an innovative path of development are guided by the following areas of innovation:

- creation of new service or new variety of an existing service,

- introduction of effective technological process,

- search for a new or improved way of providing a tourism product,

- use of new tourism resources not previously used,

- search and development of a new market (new markets) sales,

- implementation of organizational changes.

Innovation activities should be aimed at solving the tasks formulated in the Latvian tourism policy planning documents: increasing the number of multi-day travelers, reducing the seasonality effect, increasing the occupancy rate of accommodation facilities for tourists from off-season, ensuring the growth of the tourism product profitability, as well as the annual increase in the country's tourism product export. 
According to European Innovation Scoreboard (EIS) for 2019, Latvia remains in Moderate Innovators group, however, it should be noted that in general innovation index has increased. At the same time, venture capital spending increased significantly. It should be noted the positive trends in the innovative activity of small and medium enterprises in Latvia, which include the majority of tourism industry enterprises. The innovative scoreboard shows that since 2011 there has been significant increase in marketing or organizational innovations in small and medium enterprises and the total number of innovators. At the same time, number of indicators worsened, for example, $R \& D$ expenses in the business sector, as well as innovative expenses not related to $R \& D$.

Table 2. Changes in Latvian innovation sector between 2011 and 2018

\begin{tabular}{|l|c|c|}
\hline Indicator & $\mathbf{2 0 1 1} \mathbf{y} \cdot$ & $\mathbf{2 0 1 8} \mathbf{y} \cdot$ \\
\hline Summary innovation index & 48,0 & 60,3 \\
\hline R\&D expenditure in the public sector & 36,5 & 37,4 \\
\hline Venture capital expenditures & 15,0 & 148,2 \\
\hline Firm investments & 69,0 & 46,4 \\
\hline R\&D expenditure in the business sector & 17,6 & 8,6 \\
\hline Non-R\&D innovation expenditures & 149,4 & 90,4 \\
\hline Innovators & 24,7 & 39,7 \\
\hline SMEs product/process innovations & 34,4 & 41,0 \\
\hline SMEs product/process innovations & 11,6 & 43,4 \\
\hline Intellectual assets & 65,1 & 53,5 \\
\hline
\end{tabular}

Source: European Innovation Scoreboard, 2019

The main challenges to competitive and sustainable development tourism in Latvia are:

- Reduced average tourist spending per day. Although the number of tourists is growing and exceeded forecasts by $8 \%$, their total expenses did not reach the expected level due to decrease in average expenses per tourist per day.

- Strong seasonality of tourism, leading to fluctuations in business activity. The average occupancy rate of hotel rooms in low season drops to $30 \%$, and in the high season it can reach $60-80 \%$.

- Low competitiveness of Latvia as a tourist destination in the region, EU and around the world. Latvia is relatively unknown as a tourist destination, and it is important to increase the recognition of this tourism market.

An assessment of the current situation and challenges in the tourism sector shows that one of the significant problems is limited resources and the inability to offer tourism product that meets the requirements of the modern market, as well as to ensure its thoughtful promotion on the market. In these conditions, the state tourism policy is aimed at: 
- promoting investment in the development of existing tourist facilities and offers, taking into account the internal potential of the territory of Latvia and the existing indicators of tourism development

- assistance in the creation of new tourist facilities in areas where there are prerequisites for the further development of tourism, for example, fame, availability of tourist flow, additional services (accommodation facilities for tourists, meals, wellness services, resort infrastructure and natural healing resources).

"Basic Guidelines for the Development of Latvian Tourism Period 2014-2020" as strategic types of Latvian tourism define:

1. Tourism MICE (deals and events).

2. Health tourism.

3. Natural tourism.

4. Cultural tourism.

Successful development of these types of tourism is impossible without an innovative component. So, health tourism today is developing in direction from the natural resource to investment and innovation stage of development, in which the available natural resources lose their leading role in the formation of competitive advantages in the tourism market.

Table 3. Health tourism categories in Latvia

\begin{tabular}{|l|l|}
\hline \multicolumn{1}{|c|}{ Category } & \multicolumn{1}{c|}{ Example } \\
\hline SPA\&Wellness tourism & SPA-programs, detox-programs, cosmetology services \\
\hline Rehabilitation / spa treatment & $\begin{array}{l}\text { Physiotherapy, medical rehabilitation, } \\
\text { spa treatment programs, including spa healing resources }\end{array}$ \\
\hline Export of medical services & $\begin{array}{l}\text { Diagnostics, dentistry, bariatrics, ophthalmology, oncology, } \\
\text { orthopedics, plastic surgery, dermatology, etc. }\end{array}$ \\
\hline Ethnoscience & Country baths, herbal teas, gifts of nature \\
\hline
\end{tabular}

Source: Latvijas Investīciju un attīstības aǵentūra, 2018

Clusters play an important role in the innovative development of tourism industry today.

One of the first authors to define cluster was suggested by Michael Porter: "Clusters are a group of geographically neighboring interconnected companies (suppliers, manufacturers, etc.) and related organizations (educational institutions, government bodies, infrastructure companies) operating in a certain field and complementary each other" (Porter, M., 2000). The definition of M. Porter is consonant with the definition of a cluster by the European Commission: "Clusters are a set of enterprises and related supporting institutions that closely cooperate in a specific area (region)" (European Commission, 2020).

In 2012, Latvian Health Tourism Cluster found, purpose to offer quality medical services to foreign patients and local residents. Initially, it consisted from 22 participants, and in 2016 already 60 participants merchants of wide range of health tourism services: resort rehabilitation centers, public and private hospitals and clinics, surgical centers, dental and eye clinics, SPA hotels and SPA centers, eco-cosmetics 
manufacturers, travel agencies, research and educational institutions, local governments in a number of cities (Jurmala, Carnikava, Saulkrasti, Sigulda, etc.), non-governmental organizations.

Participation in this cluster makes it possible to improve cooperation between those working in health tourism sector, carry out joint marketing activities, create and offer the market an integrated, innovative tourism product, while making it more accessible to both local and foreign tourists. The main activities of this cluster are:

- Joint marketing activities,

- Workshops, meetings and exhibitions abroad,

- Cooperation of enterprises in creating a comprehensive offer in the field of health tourism,

- Creation of new and innovative products that use Latvian therapeutic agents (cluster + research institutions),

- Cooperation between cluster partners and higher education institutions,

- Providing regulatory framework for health tourism (medical visas, obtaining resort status, etc.) (The Latvian Health Tourism Cluster).

In 2013, a memorandum of cooperation was signed between Lithuanian medical tourism cluster, Latvian health tourism cluster and Estonian health tourism cluster, which resulted in creation of the Baltic Medical Tourism Cluster. This cluster was created to solve a number of common problems - increasing competitiveness of the Baltic region in the field of health tourism services, developing common standards for the quality of services provided, pooling the resources of three countries for joint promotion to foreign markets.

The problems on path to successful development of the cluster of health tourism services in Latvia include statistics and accounting, the unformed image of Latvia as an exporting country of health tourism services, an uneven level of quality of services provided, insufficient resources for marketing activities abroad, etc. As one of the priorities identified need to separate medicine and Wellness. SPA \& Wellness tourism is relatively new but rapidly developing direction of health tourism, in which the innovative component is most pronounced. Most hospitality industry experts point to steady increase in the number of modern tourists, whose needs as an indispensable component during the trip include getting wellness and SPA procedures. However, today in the legal acts, among specialists and at the household level, there is a certain confusion in definitions of health, medical and SPA \& Wellness tourism. Thus, Latvian Tourism Law defines the term "health tourism" as a type of tourism, the purpose of which is to improve the general condition and well-being of the body, prevention, treatment and rehabilitation, using also natural healing resources" (LR Saeima, 1999). In addition to this definition, the Tourism Law provides the definition of "recreational tourism", which is defined as a type of tourism, the purpose of which is to restore the physical and mental potential of person, with the rational use of natural and artificial resources of recreation and recreation. In this regard, it should be noted that the use of term "recreational tourism" from methodological 
point of view is inaccurate, since tourism itself is part of recreation, because in any type of tourism there is a recreational component.

At the same time, Law on Tourism does not contain the definitions of "medical tourism", "SPA tourism" and "Wellness tourism". This situation indicates that legal regulation in the field of tourism lags behind the realities of development of this sector of the national economy. It seems necessary to supplement the Latvian Tourism Law with the categories of "medical tourism", "SPA tourism" and "Wellness tourism" in the following formulations:

- Medical tourism - tourist trips carried out by both residents and non-residents in order to receive medical services, undergo rehabilitation, perform medical procedures, operations or preventive health recovery;

- SPA tourism - tourist trips carried out by both residents and non-residents, the main purpose of which is health improvement, relaxation and cosmetic body care by obtaining mainly water and other SPA procedures in tourist SPA destinations

- Wellness tourism - tourist trips carried out by both residents and non-residents with the aim of improving and balancing all the main components of human life, including physical, mental, emotional, professional, intellectual and spiritual, through participation in preventive, active, life-promoting events, such as fitness, healthy eating, relaxation, pampering and healing treatments.

Terminological certainty helps to classify certain types of wellness services and determine direction of innovation in the relevant field.

An important contribution to development of health tourism is made by small and medium-sized businesses, which have limited financial opportunities for innovation and marketing, but at the same time are very flexible in responding to changing market conditions and targeting specific target segments of Latvian Action Plan "Growth and Employment" for the period 2014- 2020, funded by the EU structural funds and the Cohesion Fund, under the priority direction "Competitiveness of Small and Medium-Sized Businesses" provides support for new businessmen, growth of existing businessmen, promotion of access to financing for businessmen, provision of services to business incubators (consultations, mentoring, seminars). This program is also aimed at assisting in the development of foreign markets and strengthening Latvia's international competitiveness in the field of MICE1 and health tourism, and at developing clusters. Under this program, 4418.2 million EUR are available (LR Ministru kabinets, 2015).

An important task for the innovative development of health tourism is provision of enterprises with qualified personnel meeting market requirements. In particular, this issue is extremely relevant for Latvian companies operating in the field of SPA \& Wellness tourism, experiencing a shortage of specialists in this service sector. In 2010, SPA-master profession was included in Latvian standard of professions, later on the recommendation of experts renamed to "SPA-specialist".

Today, number of professional school's train SPA-specialists and SPA-administrators, however, the actual problem for Latvia at this moment is the provision of enterprises with SPA-managers. 
There is no "Wellness Specialist" profession in Occupational Standard, which is an obstacle to the development of appropriate curricula in educational institutions at various levels. The main directions of the development of education for the period 2014-2020 are aimed at solving this problem, providing for the facilitation of cooperation between educational institutions and employers, the development of professional educational programs and standards of professions that meet the needs of the industry.

The unresolved problem remains the standardization of SPA and Wellness services. At one time, representatives of Latvian SPA-school, with the assistance of experts, developed the standard "SPA operators and services", which includes a classification and certification system for SPA. But, at this moment, this system is not implemented everywhere.

Also, standard has not been developed that sets out the basic provisions and regulatory requirements for Wellness facilities and Wellness operators. Meanwhile, the standardization of these services is aimed at solving a number of problems, among which - promoting the development of innovative activities in SPA and Wellness industry, including its tourism sector.

Successful development of SPA and Wellness tourism sector is impossible without a constant search for product innovations. So, Latvian resort city of Jurmala has a long tradition of a medical resort. In late 1980s, 24 sanatoriums, 34 boarding houses and rest houses, three campsites, two hotels worked in Jurmala. Today in Jurmala, offer of SPA and Wellness services is more developed, although in recent years, rehabilitation and medical services have begun to develop and popularize more actively.

Six institutions provide rehabilitation and spa treatment services in Jurmala:

- Resort rehabilitation center "Jaunkemeri",

- National rehabilitation center "Vaivari",

• Rehabilitation center "SIVA",

- Sanatorium "Belarus",

- Sanatorium "Amber Coast",

- Clinic "Dzintari".

In turn, SPA and Wellness services in Jurmala provided by 10 SPA centers, 16 cosmetology centers, 12 pools, 21 bath complexes operating in hotels, resorts, Livu water park. The range of services offered by SPA and Wellness is dominated by Russian and Oriental traditional products (Russian bath, Thai massage, etc.), however, no emphasis is placed on products typical for Latvia (traditions of the Latvian bath, procedures using Latvian healing herbs, honey, etc.) This situation gives a certain direction to the development of product innovations in the field of health tourism.

One of the most important areas for the development of the health tourism sector in Latvia is the revival of the resort industry. In this direction, Latvian Association of Resort Towns operates, purpose of which is to promote the development and adoption of regulations governing the activities of resorts, the development and expansion of the resort towns of Latvia. One of the main tasks of the Association is to obtain state support in developing the infrastructure of resort cities, which helps to attract tourists and vacationers, as 
well as expanding the circle of Latvian territories that have received resort status. The members of the Latvian Association of Resort Cities are currently nine municipalities and 50 entrepreneurs. The revival and development of the Latvian resort industry will undoubtedly contribute to the growth of innovative activity in this area.

A condition for innovative development is introduction of technological innovations, involving the use of new equipment and technologies in the development, promotion and provision of tourism services, including the introduction of modern information technologies, without which it is impossible to imagine the activities of the modern tourism industry. Innovative enterprises of rapid growth such as start-up can also play an important role in this process (Pukała \& Petrova, 2019).

Technological innovations are used in all major business processes within a tourism enterprise, from finding and attracting customers as a communication and marketing tool, and ending with the formation of a tourism product.

Market innovations in field of health tourism are also associated with improving marketing strategies for promoting a tourism product, introducing new marketing communication tools (social media, online branding, dynamic pricing, targeting and market segmentation using modern information technologies). It is assumed that in the future the virtual connection of SPA and Wellness with clients will become much more creative, unique innovative forms of attracting customers to the network will appear, in particular, special diagnostic technologies and compiling individual programs online taking into account the specific characteristics of the client, consultations with a trainer or a cosmetologist in the mode real time. This trend of innovative development should also be adopted by Latvian companies operating in the field of SPA and Wellness tourism.

\section{CONCLUSION}

One of the significant problems hindering development of health tourism in Latvia is lack of innovation in the tourism industry, in particular health tourism sector. State policy in the field of tourism is aimed at solving this problem. An important role in the innovative development of health tourism today is played by Latvian health tourism cluster. However, for its successful development it is necessary to solve the number of problems, such as: problem of health tourism statistics in Latvia, formation Latvia's image as a destination for health tourism, determination of effective directions in marketing activities abroad. An important task is to solve the terminological certainty of health components tourism. Terminological certainty helps to classify certain types of wellness services and determine the direction of innovation in relevant field.

It is necessary to give a clear definition of SPA and Wellness tourism in Latvian Tourism Law, which are rapidly developing areas of health tourism, in which innovative component is most clearly expressed.

An important contribution of health development tourism is made by small and medium-sized businesses, which have limited financial opportunities for innovation and marketing, but at the same time are very flexible in responding to changes in market conditions and focusing on specific target segments. 
An important task for the innovative development of health tourism is provision of enterprises with qualified personnel meeting market requirements. Standardization of SPA and Wellness services will also contribute not only to improve the quality of services provided, but also introduction of product and technological innovations.

An important role in process of introducing technological innovations can also be played by innovative start-up enterprises of rapid growth.

A solution to the urgent problem for Latvia in improving marketing strategies for promoting tourism product and introducing new marketing communication tools, also possible on the basis of relevant innovations.

In general, increasing innovation activity health field is possible on effective interaction between the state, science, education and entrepreneurship. Only in this way can the long-term competitiveness of Latvian health tourism on global tourism market.

\section{Conflict of interests}

The authors declare no conflict of interest.

\section{Bibliography}

Centrālā statistikas pārvalde (2020). 2019. gadā Latvijas tūristu mītnēs apkalpoto viesu skaits pieaudzis par 1,6 \%. https://www.csb.gov.lv/lv/statistika/statistikas-temas/transports-turisms/turisms/meklet-tema/2662-latvijas-viesnicu-uncitu-turisma-mitnu (21.02.2020)

Ekonomikas ministrija (2019) Inovācija. Retrieved from: https://www.em.gov.lv/lv/nozares_politika/inovacija/

Ekonomikas ministrija (2014). Latvijas tūrisma attīstības pamatnostādnes 2014. -2020.gadam -https://www.em.gov.lv /lv/nozares_politika/turisms/dokumenti/politikas_planosanas_dokumenti/ (12.02.2020)

Ekonomikas ministrija (2019). Tūrisma politikas mērķis 2014.-2020.gadam. Retrieved from: https://www.em.gov.lv /lv/nozares_politika/turisms/dokumenti/politikas_planosanas_dokumenti/ (28.01.2020)

Europe 2020. A strategy for smart, sustainable and inclusive growth. European commission. Brussels. 2010. P.10.

European Innovation Scoreboard (2019). Latvia. Retrieved from: https://ec.europa.eu/docsroom/documents/35899

European Commission (2020). EU Cluster Portal: Retrieved https://ec.europa.eu/growth/industry/policy/cluster_en

Global Innovation Index 2018 rankings. - http://www.wipo.int/edocs/pubdocs/en/wipo_pub_gii_2018-intro5.pdf

Gryshova, I., Petrova, M., Tepavicharova, M., Diachenko, A., Gutsul, T. 2019. A model for selection of a management team to ensure the sustainability and development of the business organizations. Entrepreneurship and Sustainability Issues, 7(1), 690-703. http://doi.org/10.9770/jesi.2019.7.1(49)

Labunska, S., Karaszewski, R., Prokopishyna, O., Iermachenko, I (2019). Cognitive analytical tools for cost management of innovation activity. Problems and Perspectives in Management, 17(1), $395-407$. http://dx.doi.org/10.21511/ppm.17(1).2019.34

Labunska Sv., Petrova M., Prokopishyna O. Asset and cost management for innovation activity, "Economic Annals XXI", Volume 165, Issue 5-6, 2017, Pages: 13-18.

Latvijas statistikas gadagrāmata. - https://www.csb.gov.lv

Latvijas tūrisma attīstības pamatnostādnes 2014.-2020.gadam - https://www.em.gov.lv/lv/nozares_politika/turisms/ dokumenti/politikas_planosanas_dokumenti/ 
Latvijas Investīciju un attīstības aǵentūra (2018). Kā attīstīit tūrismu Latvijā? Tūrisma mārketinga stratēǵija 2018. 2023. Retrieved from: http://www.liaa.gov.lv/files/liaa/content/Turisms/Prezentacijas/turisma_marketinga_stra tegija_kopsavilkums.pdf (27.01.2020)

LR Ministru kabinets (2015). Par Eiropas Savienības struktūrfondu un Kohēeijas fonda 2014. -2020.gada plānošanas perioda darbības programmu "Izaugsme un nodarbinātība". Ministru kabineta rīkojums Nr.62 Retrieved from: https://www.vestnesis.lv/op/2015/26.1? search=on

LR Saeima (1999). Turisma likums. Retrieved from: https://likumi.lv/doc.php?id=50026 (28.01.2020)

Lukjanova, J., Sushchenko, O., Zima, O. (2019). Educated and competent staff as important factor of innovation development of machine-building and metalworking industry in Latvia, Sheregesh, X International Scientific and Practical Conference "Innovations in Mechanical Engineering" (ISPCIME-2019). MATEC Web of Conferences, EDP Sciences, vol.297 (06006), 2019, DOI: https://doi.org/10.1051/matecconf/201929706006

Mikhailov, V., Karasev, V., Mikhailov, G. (2018). The Study of the Main Indicators of the Local Environmental and Economic System "Industrial Enterprise-Environment". E3S Web Conf. Volume 41, 2018. III ${ }^{\text {rd }}$ International Innovative Mining Symposium, https://doi.org/10.1051/e3sconf/20184102015

Mussapirov, K., Djalkibaev, J., Kurenkeyeva, G., Kadirbergenova, A., Petrova, M., Zhakypbek, L. 2019. Business scaling through outsourcing and networking: selected case studieS, Entrepreneurship and Sustainability Issues, 7(2), 1480-1495. http://doi.org/10.9770/jesi.2019.7.2(48)

Naama, K. 2001. "International Movement of Foreign Direct Investments," Economic Thought journal, Bulgarian Academy of Sciences - Economic Research Institute, issue 5, pages 81-92. https://www.ceeol.com/search/articledetail?id=221618

Nenkov, N., Sushchenko, O., Dyachenko Y. (2017) Role of chief information officer within the system of human resource development in the service organizations (tourism) // Economic Annals-XXI. - Issue 5-6. - Vol. 165. - P. $97-103$.

Odinokova, T. (2019). Tourism cluster as a form of innovation activity. Economics. Ecology. Socium, 3 (2), 1-11.

OECD (2018), OECD Tourism Trends and Policies 2018, OECD Publishing, Paris. - http://dx.doi.org/10.1787/tour2018-en.

OECD (2019). OECD Economic Surveys: Latvia. Retrieved from: https://read.oecd-ilibrary.org/economics/oecdeconomic-surveys-latvia-2019_f8c2f493-en\#page1

Par Eiropas Savienī bas struktūr fondu un Kohēzijasfonda 2014.-2020.gada plānošanas perioda darbī bas programmu "Izaugsme un nodarbinātība "Ministru kabineta rīkojums Nr.62 https://www.vestnesis.lv/op/2015/26.1? search=on

Petrova, M., Dekhtyar, H., Klok, O., Loseva, O. Regional tourism infrastructure development in the state strategies. "Problems and Perspectives in Management", Issue 4, 2018

Petrova, M., Buzko, I., Dyachenko, Y. Cognitive, Intelligence Technologies and Economical Foundations of Teaching of International Economical Relations and Tourism. 17th International Scientific Conference ERDev, 23.25.05.2018. Jelgava, LATVIA, pp. 1102-1106, DOI: 10.22616/ERDev2018.17.N170

Politikas plānošanas dokumenti - https://www.em.gov.lv/lv/nozares politika/turisms/dokumenti/politikas planosa nas dokumenti/

Porter, M. (2000), "Location, competition, and economic development: local clusters in a global economy", Economic Development Quarterly, 14 No.1. - http://journals.sagepub.com/doi/pdf/10.1177/089124240001400105.

Pukala R., Petrova, M. (2019). Application of the AHP method to select an optimal source of financing innovation in the mining sector. E3S Web of Conferences Volume 105 (2019). IV ${ }^{\text {th }}$ IIMS, Kemerovo, Russian Federation, October 14-16, 2019, DOI: https://doi.org/10.1051/e3sconf/201910504034

Skaistumkopšanas nozares kvalifikāciju struktūra. -https://visc.gov.lv/profizglitiba/.../NKS_skaistumkopsana.pdf

Sushchenko O., Petrova M. (2017) Internet Marketing as a Tool of Tourism Enterprise Strategic Management // Modern problems of enterprise management: theory and practice: materials Intern. of sciences. - practice. Conf., March 30-31. 2017 - Kharkiv, Semen Kuznets Kharkiv National Economic University, 2017. - C. 302-305.

Sushchenko, O. (2016). Creation of innovation clusters as a line of enterprise competitiveness improvement in the field of foreign economic activity, Actual Problems of Economics, 177(3), 191-198

Tepavicharova, M., Dikova, L., Zahars, V. (2019). Development of a competency model for selection of human resources in the mining and quarrying sector in Bulgaria. IV th International Innovative Mining Symposium E3S Web of Conferences, Vol. 105. Ed. by Tyulenev M.; Zhironkin S.; Khoreshok A.; Vöth S.; Cehlár M.; Nuray D.; 
Janocko J.; Anyona S.; Tan Y.; Abay A.; Marasová D.; Stefanek P. October 14-16, Kemerovo, Russian Federation, https://doi.org/10.1051/e3sconf/201910504029

The Latvian Health Tourism Cluster. Retrieved from: https://healthtravellatvia.lv/en/cluster/(26.01.2020)

Travel\&Tourism Economic impact 2018 World. - https://www.wttc.org/-/media/files/reports/economic-impactresearch/regions-2018/world2018.pdf

Tumalavičius, V., Veikša, I., Načisčionis, J., Zahars, V., \& Draskovic, V. (2017). Issues of the state and society security (part i): ensuring public security in the fight against crime. Journal of Security \& Sustainability Issues, 6(3), 401418. http://doi.org/10.9770/jssi.2017.6.3(7)

Tūrisms Latvijā 2018. Statistiskodatukrājums. Centrālāstatistikaspārvalde, Rīga, 2018. - 64.lpp.

Turisma likums. - https://likumi.lv/doc.php?id=50026

Tūrisma mārketinga stratēgija http://www.liaa.gov.lv/files/liaa/content/Turisms/Prezentacijas/turisma_mar ketinga_strategija_kopsavilkums.pdf

UNWTO (2020). World Tourism Barometer. Volume 18 - Issue 1 - January 2020. Retrieved from: https://webunwto.s3.eu-west-1.amazonaws.com/s3fs-public/202001/UNWTO_Barom20_01_January_excerpt_0.pdf) (26.01.2020)

Valsts izglītības satura centrs (2020). Skaistumkopšanas nozares struktūrā ieklauto profesiju karte. Retrieved from: https://visc.gov.lv/profizglitiba/dokumenti/nozkval/NKSK_skaistumkopsana.pdf (17.02.2020)

World Tourism Organization (2018), UNWTO Tourism Highlights, 2018 Edition, UNWTO, Madrid, DOI: https://doi.org/10.18111/9789284419876

World Travel \& Tourism Council: Travel \&Tourism Power and Performance -September $2018 . \quad-$ https://www.wttc.org/- /media/files/reports/2018/power-and-performance-rankings-2018.pdf

\section{About the authors:}

\section{Jelena LUKJANOVA}

PhD of Economics, Associate Professor, Head of Management Department, ISMA University, Latvia. Research interests: innovation, innovation management, small and medium enterprises, regional and rural tourism, cluster, crossborder cooperation, resort, economic growth.

ORCID ID: http://orcid.org/0000-0002-2825-6572

\section{Tatyana ODINOKOVA}

PhD of Economics, Associate Professor, Department of Economics, ISMA University, Latvia. Research interests: innovation, innovation activity, start-up, small and medium enterprises, economic growth.

ORCID ID: http://orcid.org/0000-0002-9310-3214 